\title{
Konsep Tasawuf Ibnu Atha'illah al-Sakandari dan Relevansinya dengan Konseling Psikosufistik
}

\author{
Muhammad Taufiq Firdaus \\ Universitas Islam Negeri Sunan Kalijaga Yogyakarta \\ taufiqfirdaus27@gmail.com
}

\begin{abstract}
This study is the branch of the big topic concerning Islamic counseling that is exclusively studied through Sufism approach. The Sufism concept of Ibn Athaillah in Kitab Al-Hikam is described in order to be an approach of Islamic counseling as the result of the harmonious combination between psychology and Sufism to actualize human mental health. The scope of this study is focused on the main problem namely how Sufism concept of Ibn Athaillah can be used as counseling approach. The method used in this study is literature review type qualitative approach. The primary data are collected from Kitab Al-Hikam by Ibn Athaillah As-Sakandari. The secondary data are collected from various supporting literatures concerning Sufistic counseling. Data are collected using documentation method. Then, the data are reduced and analyzed. The result of this study indicates that Sufism concept is always focused on heart and soul management in order to draw closer to Allah. This can be made to be one of approaches in Islamic counseling. Sufism concept of Ibn Athaillah stresses more on riyadhah al-qulub namely emphasis in the aspect of heart condition in guiding someone that wants to go to the path of goodness. The conclusion is that in conducting spiritual counseling, Sufism approach is relevant to be the basis and spiritual counseling method. Riyadhah al-qulub or emphasis on heart aspect is psychosufistic counseling based on Sufism concept of Ibn Athaillah As-Sakandari.
\end{abstract}

Keywords: Ibnu Athaillah; Psychosufistic; Counseling

\begin{abstract}
Abstrak
Penelitian ini sebagai turunan dari topik besar konseling islam yang secara khusus dikaji melalui pendekatan ilmu tasawuf.
\end{abstract}


Mendeskripsikan Konsep tasawuf Ibn Athaillah dalam kitab alhikam untuk dijadikan suatu pendekatan konseling islami sebagai hasil dari perpaduan yang harmoni antara psikologi dan tasawuf untuk mewujudkan kesehatan mental manusia. Lingkup penelitian ini difokuskan pada permasalahan utama yakni bagaimana konsep tasawuf Ibn Athaillah dapat digunakan sebagai pendekatan konseling. Metode dalam penelitian ini menggunakan pendekatan kualitatif jenis kajian pustaka, sumber data primer diperoleh dari Kitab Al-Hikam karya Ibn Athaillah As-Sakandari, data sekunder diperoleh dari berbagai literatur penunjang yang berkaitan dengan konseling sufistik. Pengumpulan data dengan metode dokumentasi, kemudian data tersebut di reduksi data dan analisi isi. Hasil dari penelitian ini menunjukkan bahwa konsep tasawuf Ibn Athaillah AsSakanadari selalu terkonsentrasi pada pengelolaan hati dan jiwa dalam rangka mendekatkan diri kepada Allah swt. Hal ini dapat dijadikan sebagai salah satu pendekatan dalam konseling islami. Konsep tasawuf Ibn Athaillah lebih menekankan riyadah al-qulub yakni penekanan dalam aspek kondisi hati seperti ikhlas, ridha, sabar, tawadhu', tawakal, raja', khauf dan bersyukur untuk membimbing seseorang yang hendak menuju ke jalan kebaikan. Riyadah al-qulub merupakan metode konseling psikosufistik menurut konsep ilmu tasawuf Ibn Athaillah as-Sakandari. Maka dalam melakukan konseling islami, pendekatan ilmu tasawuf Ibn Athaillah dapat dijadikan sebagai basis dan metode konseling spiritual.

Kata Kunci: Ibnu Athaillah; psikosufistik; konseling

\section{Pendahuluan}

Konseling psikosufistik merupakan konseling yang hadir sebagai bentuk harmonisasi dari ilmu psikologi dan ilmu tasawuf dengan konsep yang khas. ${ }^{1}$ Sehingga menghasilkan konsep metode dan teknik konseling yang khas pula dalam pelaksanaannya dengan tujuan yang lebih spesifik, yakni dengan berdasarkan nilai-nilai tasawuf keislaman. ${ }^{2}$ Konseling psikosufistik berbeda dan juga lebih khusus dari pada konseling pada umumnya, karena konseling psikosufistik khusus pada konseling yang islami (berlandaskan tasawuf). Konseling psikosufistik dalam melakukan proses konseling menggunakan pendekatan berdasarkan pada pendekatan psikologi dan pendekatan tasawuf.

${ }^{1}$ Zamzami Sabiq, "Konseling Sufistik: Harmonisasi Psikologi Dan Tasawuf Dalam Mewujudkan Kesehatan Mental," 'Anil Islam: Jurnal Kebudayaan dan Ilmu Keislaman 9, no. 2 (December 31, 2016): 328-352.

2 Ahmad Fauzi, "Psikosufistik Pendidikan Islam Dalam Perspektif Pemikiran Syekh Ibnu Athaillah," Jurnal Intelektual: Jurnal Pendidikan dan Studi Keislaman 8, no. 2 (August 1, 2018): 229-240. 
Psikosufistik di artikan atau didefinisikan sebagai sebuah kajian tentang tingkah laku ataupun perbuatan manusia dengan konsep yang dibangun diatas ilmu tasawuf yang berlandaskan al-Quran dan al-Hadits. ${ }^{3}$

Penerapan psikosufistik lebih fokus mengembangkan potensi batin manusia ke arah kesadaran psikologis untuk senantiasa dekat dengan Allah. ${ }^{4}$ Aspek yang dikedepankan ialah citra (dzawqiyah) rasa serta penyucian diri (tazkiyah al-nafs) ${ }^{5}$. Meskipun dalam hal ini masih banyak perdebatan dari pihakpihak yang pro dan kontra. Pihak yang menolak dengan pengembangan konseling islami ialah mereka yang tidak sependapat dan tidak mengakui adanya ruang atau dimensi spiritualitas yang menjadi objek kajian utama dalam konsep bimbingan konseling islami. Adapun mereka yang pro dan selalu memerjuangkan konseling islami ialah para cendikiawan dan peneliti muslim, dari pengembangan konsep tersebut mereka memang benar menemukan hasil yang berbeda. Hal ini akan memperkuat pengembangan konsep konseling islami dalam dunia konseling. ${ }^{6}$

Pandangan psikosufistik terhadap gangguan kesehatan mental yang di alami manusia modern adalah karena kekosongan spiritual. ${ }^{7}$ manusia modern menjalani kehidupan dengan pola hidup konsumtivisme. ${ }^{8}$ dan individualisme yang semakin menjadi-jadi di banyak dunia modern. ${ }^{9}$ Kehampaan spritual yang di alami manusia modern mengakibatkan munculnya gangguan kejiwaan, seperti stres dan galau. Pada umumnya penyakit ini sulit disembuhkan melalui medis, maka tentunya penyakit batin hanya bisa disembuhkan melalui psikologisnya dengan metode rohaniah ataupun dengan pendekatan dan pengobatan sufistik. ${ }^{10}$

Amin Syukur menjelaskan bahwa ilmu tasawuf dapat digunakan sebagai pendekatan dan terapi untuk kesehatan mental yakni: 1) secara psikologis kajian tasawuf yakni hasil dari suatu pengalaman spiritual maupun bentuk pengetahuan

3 Ubaidillah Achmad, "Teori Kehendak Manusia Perspektif Psiosufistik Al-Gazali," Konseling Religi 6, no. 2 (2015).

${ }^{4}$ Abdullah Hadziq, Rekonsiliasi psikologi sufistik dan bumanistik (Rasail, 2005).

${ }^{5}$ Abdul Mujib, "Model Kepribadian Islammelalui Pendekatan Psikosufistik,” Nuansa 8, no. 1 (2015).

6 Muhamad Rifa'i Subhi, "Development of Islamic Counseling Concept (spiritual Issues in Counseling)," Hisbab: Jurnal Bimbingan Konseling dan Dakwah Islam 13, no. 1 (June 1, 2016): 121-134.

7 Ahmad Nurcholis, "Peran Tasawuf Dalam Merekonstruksi Krisis Spiritualitas Manusia Modern," Sosio Religi (2012).

8 Heldi Heldi, "Pola Konsumsi Masyarakat Post-Modern (Suatu Telaah Perilaku Konsumtif Dalam Masyarakat Post-Modern)," Al-Iqtishad: Jurnal Ilmu Ekonomi Syariah 1, no. 1 (7 Januari 2009), https://doi.org/ 10.15408/ aiq. v1i1.2458.

9 Alia Azmi, "Individualisme Dan Liberalisme Dalam Sekularisme Media Amerika," Humanus 12, no. 1 (June 28, 2013): 33-42.

10 Muhammad Amin Syukur, "Sufi Healing: Terapi Dalam Literatur Tasawuf," Walisongo: Jurnal Penelitian Sosial Keagamaan 20, no. 2 (December 15, 2012): 391-412. 
mengenai keberadaan atau realitas ketuhanan yang cendrung menjadi indikator dalam agama. 2) merasakan kehadiran atau keberadaan Tuhan dalam bentuk pengalaman mistis kemudian menimbulkan dan menjadikan keyakinan yang sangat kuat. Perasaan dan pengalaman mistis tersebut seperti ma'rifat, ittihad, bulul, mahabbah, uns, hal-hal tersebut dapat menjadikan moral force bagi amalamal saleh. 3) seseorang dalam menjalani hubungan dengan Allah dijalani atas rasa kecintaan, para pengamal sufistik Allah bukanlah suatu Dzat yang menakutkan, tetapi Allah adalah Dzat yang penyayang, pengasih, pemurah, sempurna, kekal, indah dan selalu hadir dimanpun dan kapanpun. Hasil dari hubungan hamba dengan Allah sebagai moral kontrol akan mendorong seseorang untuk melakukan sesuatu yang baik, kemudian menghindari dari penyipangan perbuatang yang tercela. ${ }^{11}$

Studi tentang pemikiran tasawuf Ibn Attaillah Asakandari telah banyak dibahas dengan berbagai topik dan tema, pembahasan tersebut seputar konsep tasawuf Ibn Athaillah dan relevansi, kontribusinya dengan disiplin ilmu lainya seperti ilmu pendidikan dan ilmu psikologi. ${ }^{12}$ ada yang mencoba melihat pemikiran Ibn Athaillah di dalam kitab al Hikam suatu kajian tentang kontribusi nilai dan konsep tasawuf dalam pendidikan islam. ${ }^{13}$ Kemudian studi yang menggali corak tasawuf dalam al-Hikam Ibn Athaillah penerapan dan implikasinya terhadap pembentukan akhlak di pondok pesantren. ${ }^{14}$ Kemudian ada yang mengkaji dan membahas mengenai nilai pendidikan karakter dalam pemikiran Ibn Athaillah As-Sakandari. ${ }^{15}$ Selanjutnya pembahasan yang bertujuan menganalisa dan mendiskripsikan pemekiran pendidikan sufistik Ibn Athaillah dan relevansi dengan pendidikan karakter di Indonesia. ${ }^{16}$

11 Ibid.

12 Muhammad Nurdin, Muhammad Harir Muzakki, and Sutoyo Sutoyo, "Relasi Guru Dan Murid (Pemikiran Ibnu 'Athaillah Dalam Tinjauan Kapitalisme Pendidikan)," Kodifikasia 9 , no. 1 (2015): 121-146; Hanifah Fauziyyah, "Konseling Sufistik Dalam Pembinaan Akhlak Siswa: Studi Kasus Di Pondok Pesantren Al-Falah 2 Nagreg" (2019); Mucharor Mucharor, "Pendidikan Akhlak Dalam Kitab Al-Hikam Karangan Syaikh Ibnu Athaillah Al-Syukandari” (2015).

13 Azizah Aryati, "Pemikiran Tasawuf Syeikh Ibn 'Atoillah as-Sakandari Dalam Kitab Al Hikam (Kajian Tentang Rekonstruksi Dan Kontribusi Nilai-Nilai Tasawuf Dalam Pendidikan Islam)," Manhaj: Jurnal Penelitian dan Pengabdian Masyarakat 6, no. 1 (2017), accessed April 24, 2020, https://ejournal.iainbengkulu.ac.id/index.php/manhaj/article/view/746.

14 Muhammad Arifudin, "Corak Tasawuf Kitab Hikam Karya Ibn 'Athaillah AsSakandari Dan Implikasinya Dalam Pembentukan Akhlak Di Pondok Pesantren Mambaus Sholihin Suci Manyar Gresik" (masters, UIN Sunan Ampel Surabaya, 2018), accessed November 12, 2020, http://digilib.uinsby.ac.id/24560/.

15 Azizah Aryati and Ismail Ismail, "Nilai-Nilai Pendidikan Karakter Dalam Pemikiran Tasawwuf Ibnu Athoillah as-Sakandari" (Presented at the International Seminar on Islamic Studies, IAIN Bengkulu, 2019), 76-83, accessed November 12, 2020, http://repository.iainbengkulu.ac.id/2936/.

16 Achmad Beadie Busyroel Basyar, "Pemikiran Syekh Ibnu Athaillah as-Sakandari tentang pendidikan sufistik dan relevansinya dengan pendidikan karakter di Indonesia: Telaah 
Ahmad Fauzi mengatakan dalam penelitiannya yang berjudul Psikosufistik pendidikan Islam dalam perspektif pemikiran syekh Ibn Attaillah. ${ }^{17}$ bahwa relevansi antara pendidikan karakter dengan ajaran tasawuf Ibn Attaillah ialah dalam hal penanaman nilai. Di dalam pendidikan karakter di indonesia penanamana nilai-nilai yang ditekankan adalah nilai agama, kebangsaan dan sosial masyarakat. Dalam sufistik Ibn Attaillah yang ditanamkan adalah nilai-nilai sufistik yang berorentasi kepada pribadi yang dekat dengan Allah swt. Pendidikan karakter tidak terlepas dari kajian psikologi dan mental seseorang. Keadaan psikologis yang baik dan mental yang baik akan melahirkan sebuah karakter yang baik. Kajian psikologis sangat erat kaitannya dengan kegiatan konseling. Akan tetapi Pembahasan mengenai konsep tasawuf Ibn Athaillah Assakandari untuk dijadikan suatu konsep psikosufistik dalam konseling Islam belum banyak dikaji.

Maka penelitian ini akan mengkaji konsep tasawuf Ibnu Atha'illah dan relevansinya dengan konseling psikosufistik. sebuah proses bantuan terhadap seseorang yang mengalami kesulitan maupun mempunyai problem lahiriah maupun batiniah yang bertujuan untuk menyadarkan kembali eksistensinya sebagai hamba maupun makhluk Allah swt, yang seharusnya hidup sesuai dengan petunjuk dan ketentuan Allah swt. ${ }^{18}$ dengan hidup sesuai petunjuk dan ketentuan Allah swt, maka akan sangat mudah dalam mengatasi berbagai problem yang dihadapi dengan sikap dan mental yang kuat sesuai ajaran Islam. ${ }^{19}$ Penelitian ini memfokuskan dua aspek; yaitu bagaimana konsep tasawuf Ibnu Athaillah dan bagaimana konsep tasawuf Ibnu Athaillah tersebut dapat menjadi basis konseling psikosufistik.

Penelitian ini menggunakan metode kepustakaan (library research) yang membahas tentang konseling psikosufistik Ibn Athaillah As-Sakandari. Dengan tujuan untuk menggali lebih dalam pemikiran dan konsep tasawuf Ibn Athaillah As-Sakandari untuk diterapkan dalam konseling sufistik. Data dalam penelitian ini bersumber dari data primer dan juga data sekunder. Sumber data primer yakni kitab Al-Hikam karya syekh Ibn Athaillah As-Sakanadari. Buku yang dimakud ialah Kitab Al-Hikam Petuah-petuah Agung Sang Guru buku terjemahan dari Al-Hikam diterjemah oleh Ismail Ba'dillah. Sumber data sekunder diperoleh dari berbagai artikel jurnal maupun literatur penunjang lainya yang mengkaji

Kitab al-Hikam al-Aț āiyah" (undergraduate, Universitas Islam Negeri Maulana Malik Ibrahim, 2016), accessed November 13, 2020, http://etheses.uin-malang.ac.id/4960/.

${ }^{17}$ Fauzi, "Psikosufistik Pendidikan Islam Dalam Perspektif Pemikiran Syekh Ibnu Athaillah."

${ }^{18}$ Fahrul Hidayat, Arisatul Maulana, and Doni Darmawan, "Komunikasi Terapeutik Dalam Bimbingan Dan Konseling Islam," Hisbab: Jurnal Bimbingan Konseling dan Dakwah Islam 16, no. 2 (2019): 139-151.

19 Asriyanti Rosmalina, "Pendekatan Bimbingan Konseling Islam Dalam Meningkatkan Kesehatan Mental Remaja," Holistik 1, no. 1 (2016). 
dalam ruang lingkup konseling. Pengumpulan data dengan metode dokumentasi. Analisis data dilakukan dengan mereduksi data dan analisi isi.

\section{Hasil dan Pembahasan}

\section{Biografi Ibn Attaillah al-Sakandari}

Syekh Ahmad ibn Muhammad ibn Atha'illah as-Sakandari seorang ulama besar yang Lahir di Iskandariyah ( Mesir ) tahun 648 H/1250 M, meninggal di kairo pada tahun 1309. Mulai dari kecil Ibn Athaillah dikenal haus dengan ilmu pengetahuan terutama ilmu agama, sehingga sangat gemar dalam menuntut ilmu agama. ia mempelajari dan mendalami ilmu dari beberapa syekh, gurunya yang paling dekat beliua adalah Abu al-Abbas Ahmad ibn Ali al-Anshari al-Mursi, murid dari Abu al-Hasan al-Syadzili, yang merupakan pendiri tarekat al-Syadzili. Ibn Athaillah adalah seorang ulama yang produktif, total ada dua puluh karya yang dihasilkannya, meliputi bidang tasawuf, akidah, ushul fiqih, nahwu, hadits, dan tafsir. Dari hasil karnya tersebut yang paling terkenal ialah kitab al-Hikam, karya kitab ini telah banyak di syarah oleh ulama-ulama berikutnya, antara lain oleh Muhammad bin Ibrahim Ibnu Ibad ar-Rundi, dan Ahmad ibn Ajiba, syeikh Ahmad Zarruq. ${ }^{20}$

Ibn Athaillah merupkan seorang ulama yang dikenal karena kepribadiannya yang bersih, seorang tokoh yang di jadikan panutan dalam meniti jalan menuju Tuhan yaitu Allah swt. ulama yang mengajarkan keikhlasan, dan memberikan nasihat-nasehat agama yang begitu dalam. Ibn Athaillah dikenal sebagai guru ketiga dalam tarekat syadzili setelah pendiri-pendiri tarekat tersebut yakni Abu al-hasan asy-syadzili dan Abu al-Abbas al-Mursi. Meski dia dikenal sebagai syekh di sebuah tarekat, tetapi pengaruh intelektualnya tidak terbatas di terekatnya saja, tetapi karya-karya Ibn Athaillah di baca luas oleh kaum muslimin, bersifat lintas tarekat maupun mazhab terutama kitan al-Hikam ini karyanya yang cukup fenomenal.

\section{Pemikiran Ibn Athaillah As-Sakandari}

Pemikiran Ibn Athaillah mengenai timbulnya berbagai masalah dan problem kehidupan yang dialami oleh seorang individu sesuai dengan konsep tasawuf Ibn Attaillah yakni dikarenakan oleh penykit hati ( آفة النفس ) penyakit hati ini akan menimbulkan beberapa perkara buruk dan akhlak tercela yang mengakibatkan jauh dari Allah swt. Beberapa perkara buruk menurut Ibn Attaillah yang harus dijauhi ialah :

Pertama, Menunda amal ibadah. Ibadah yang bersifat wajib harus dilakukan oleh setiap muslim, tidak ada alasan bagi seseorang muslim untuk

${ }^{20}$ Syaikh Ibn Atha'illah As-Sakandari, Kitab Al-Hikam, Petuah-Petuah Agung Sang Guru, trans. Ismail Ba'adillah (Jakarta: Khatulistiwa Press, 2017). 
meninggalkan kewajiban beribadah tersebut selama ia tidak memiliki udzur yang dibenarkan oleh syar'i sehingga diperbolehkan dia untuk tidak melaksanakan kewajiban tersebut. konsekuensi jika meninggalkan ibadah tersebut akan mendapat murka Allah swt. Sesorang tidak meningalkan amal ibadah tetapi menunda-nundanya merupakan tanda tidak bersyukurnya seorang muslim kepada Allah swt dan termasuk kebodohan hati sebagaimana ucapan Ibn Ataillah. ${ }^{21}$

$$
\text { إحالتك الأعمال على وجود الفراغ من رعونات النفس }
$$

Menunda pelaksanaan ibadah untuk mencari waktu senggang adalah timbul dari kebodohan bati.

Sifat menunda tersebut jika disebabkan oleh urusan dunia maka akan menimbulkan lupa akan kematian yang bisa menghampiri setiap saat, dan jika senang menunda amal ibadah akan menimbulkan lemahnya niat dan tujuan yang ingin di capai dari amal tersebut. hal tersebut akan berubahnya niat dan tujuan amal itu. ${ }^{22}$

Kedua, Su'udzan kepada Allah swt. Berburuk sangka kepada Allah merupakan tanda tipisnya iman seseorang dan mengakibatkan dosa besar jika berburuk sangka terhadap Allah swt. Pada dasarnya seorang hamba harus menganggap semua pemberian Allah itu merupakan anugrah baik sesuatu tersebut baik maupun buruk, karena di balik kesusahan yang menimpa seorang hamba pasti tersimpan kebahagiaan seperti ucapan Ibn Ataillah.

$$
\text { من ظنّ إنفكاك لطف عن قدره فذالك لقصونظره }
$$

Barangsiapa yang mengira lenyapnya kasih sayang Allah dari ketetapan Allah, maka yang seperti ini adalab karena dangkalnya pandangan keimanan.

Seorang hamba hseharusnya melihat pemberian Allah swt menggunakan pandangan rohaniyah, dengan itu dia dapt merasakan hakikat dari pemberian Allah swt dan memunculkan sifat khusnudhan pada Allah swt. Akibat dari dangkalnya pandangan adalah, ia tidak mampu untuk menyaksikan adanya karunia Allah dalam setiap musibah yang ditakdirkan oleh-Nya. Dan semua ini bermuara pada lemahnya keimanan seseorang. ${ }^{23}$

Ketiga, meremehkan amal. Perbuatan yang sepele terkadang malah mendatangkan pahala, keuntungan dan keutamaan yang besar jika di niatkan tulus karena Allah. Amal perbuatan yang berat dan memerlukan daya, upaya bahkan memerlukan biaya besar tidak menjamin kualitas amal mendapat pahala besar dan keuntungan jika niat dalam mengerjaknnya tidak tulus karena Allah

${ }^{21}$ Muhammad Luthfi Ghozali, Percikan Samudra Hikmab: Syarab Hikam Ibnu Atho'illah As-Sakandari (Kencana, 2011).

${ }^{22}$ Ibn Atha'illah As-Sakandari, Kitab Al-Hikam, Petuah-Petuah Agung Sang Guru.

${ }^{23}$ Ibid. 
swt. Amalan yang diterima oleh Allah adalah, segala apa yang dilakukan hamba dengan didasarkan pada keyakinan bahwa amal itu terjadi karena taufiq dan hidayah dari Allah semata, kemudian dilaksanakan secara istiqomah. Ungkapan Ibn Ataillah tentang hal ini sebagai berikut.

$$
\text { لأعمل أرجى القبول من عمل يغيب عنك شهوده ويحتقر عنك وجوده }
$$

Tidak ada amal yang lebih diharapkan memperoleb pabala, dari pada amal yang kamu lihat enteng, dan engkau angsap remeh keberadaaanya.

Amalan yang diterima oleh Allah adalah, segala sesuatu yang dilakukan seorang hamba dengan didasarkan pada keyakinan bahwa amal itu dapat dikerjakan karena taufiq dan hidayah dari Allah semata. kemudian diikuti dengan sikap istiqomah dan tidak berbangga diri atasnya. Sebab, jika seseorang hamba merasa bangga dengan amalnya tersebut, maka amalan itu menjadi tidak bernilai dalam pandangan Allah swt. ${ }^{24}$

Keempat, sedih dan malas beribadah. Seseorang menyesal jika ketinggalan atau tidak sempat mengerjakan aktifitas ibadah merupakan sifat yang baik, namun rasa menyesal ini dibarengi dengan malas untuk melaksanakan ibadah tersebut hal ini merupakan kemunafikan sebagaimana yang diungkapkan Ibn Ataillah

$$
\text { الحزن علي فقدان الطاعة مع عدم النهوض العلامات الإغترا }
$$

Sangat sedih karena tidak bisa menjalankan ketaatan kepada Allah, akan tetapi merasa malas untuk. melakukannya adalah tandanya ia terperdaya oleh setan.

Apabila seseorang sedih karena tertinggal melakukan suatu amal kebaikan, namun ketika mendapat kesempatan tidak segera menunaikannya (menundanya), maka itu pertanda seseorang telah dipermainkan oleh tipu daya setan..$^{25}$

Seorang hamba Dalam menjalankan ibadah pasti mengalami banyak kendala yang selalu menghalangi dia untuk beribadah, halangan tersebut salah satunya disebabkan karena bisikan setan, godaan iblis dan hawa nafsu. Seorang hamba yang memiliki iman yang lemah menjadi sangat mudah di hinggapi rasa malas dalam melaksanakan ibadah. Tetapi seorang hamba tidak dibenarkan untuk berputus asa atas rahmat Allah dengan terus bermujahadah. ketakwaan dapat ditingkatkan karena kualitas ketakwan seseorang bersifat dinamis hal ini akan tergantung dengan sebesar apa usaha yang dilakukannya. Dari penyakit hati yang dipaparkan tersebut akan melahirkan berbagai problem kehidupan dengan berbagai masalah yang dihadapi oleh seseorang, hal ini tentu dilihat dari perspektif sepritualitas khusunya dalam kajian ilmu tasawuf. Semua problem yang dialami dan kesulitan yang menimpa seseorang bersumber dari hati yang

\footnotetext{
${ }^{24}$ Ibid.

${ }^{25}$ Ibid.
} 
sakit. Maka untuk mencegah dan mencari solusi dari problem yang dihadapi hendaknya seseorang menjaga hati supaya sehat sehingga hati tidak sakit yang bisa menimbulkan problem-problem kehidupan yang sangat parah.

\section{Konsep Tasawuf Ibnu Athailah Asakandari Sebagai Basis Konseling Psikosufistik}

Menurut para ahli bimbingan di tanah air munculnya konseling psikosufistik di latar belakangi oleh adanya kelemahan-kelemahan pendekatan konseling yang selama ini diterapkan. Model konseling telah banyak dikembangkan dalam upaya memberikan solusi dari berbagai masalah yang dihadapi manusia, tetapi menurut pandangan MD. Dahlan bahwa pijakan dalam mengembangankan model tersebut lebih menekankan pada bidang filsafat dan sains yang memiliki karakter spekulatif dan tentative (kebenaran yang belum pasti dan untuk sementara waktu). oleh karena itu maka hasil dari bimbingan tidak tuntas dan hanya menyentuh kulit luarnya saja. ${ }^{26}$ Saran dari para ahli bimbingan seperti Rohman Natawijaya, MD Dahlan, munandir, Djamaludin Ancok, dan Dadang Hawari, bahwa nilai-nilai agama agar dijadikan landasan dalam mengembangkan model konseling di indonesia. ${ }^{27}$

Dalam hal ini ilmu tasawuf dijadikan sebagai basis dalam pengembangan model konseling dipandang tepat, karena ajaran tasawuf dibangun berdasarkan al-Qur'an dan al-Hadits. Ajaran tasawuf fokus pada memusatkan diri atau muhasabah dan pembersihan jiwa untuk mendekatkan diri kepada Allah swt. Ilmu tasawuf dipandang memiliki banyak kesesuaian dengan ilmu psikologi yang selama ini menjadi bagian dalam pendekatan konseling. ${ }^{28}$ Alasan ini juga diperkuat karena mayoritas masyarakat indonesia menganut ajaran Islam, maka pendekatan konseling sufistik yang berlandaskan ajaran Islam diharapkan lebih efektif. ${ }^{29}$ Beberapa nilai dari ajaran ilmu tasawuf relevan untuk dijadikan pijakan dalam pendekatan psikosufistik. Dari bebrapa nilai ilmu tasawuf ini dapat dijadikan suatu kerangka pemikiran dalam membangun suatu pendekatan konseling psikosufistik. ${ }^{30}$

${ }^{26}$ Sutoyo Anwar, "Model Bimbingan Dan Konseling Sufistik Untuk Mengembangkan Pribadi Yang “Alim Dan Saleh,” Universitas Negeri Semarang 8 (2017): 4-10.

27 Anwar Sutoyo, "Bimbingan Dan Konseling Islami (Teori Dan Praktik)," Yogyakarta: Pustaka Pelajar (2013).

28 Muhamad Rifa'i Subhi et al., "Pendekatan Sufistik Dalam Bimbingan Dan Konseling," Konvensi Nasional Bimbingan dan Konseling XXI (2019): 150-156.

${ }^{29}$ Nendri Novita, Efektifitas Pendekatan Sufistik Melalui Layanan Bimbingan Kelompok Untuk Meningkatkan Kesadaran Sholat Lima Waktu Bagi Mahasiswa Iain Batusangkar (IAIN Batusangkar, 2019), accessed November 13, 2020, http://repo.iainbatusangkar.ac.id/xmlui/handle/123456789/12531.

(2014).

30 Yuliyatun Tajuddin, "Komunikasi Dakwah Walisongo Perspektif Psikosufistik" 
Pertama, nila-nilai ketauhidan. Suatu nilai ketauhidan atau kepercayaan kepada tuhan menjadi pondasi dasar dalam pembentukan kesadaran ilahiyah manusia. Seorang manusia boleh menyibukan diri dalam mengejar karir dalam kehidupannya, terus belajar, juga aktif di berbagai kegiatan, namun harus ingat dibalik kesuksesan dalam meraih itu semua ada kehendak dan ketetapan Allah swt dalam mencapai hasil akhirnya. Kautsar noer menjelaskan bahwa hakikat tasawuf ialah sebuah jalan spritual yang bersumberkan dari al Qur'an dan al Hadits dalam rangka menuju Allah swt, dengan tetap menjalankan syariat, membentuk akhlak mulia, antara kehidupan duniawi dan ukhrawi harus seimbang. Fungsi nilai ketauhidan inilah yang menjadi penyeimbang dalam kepribadian seseorang.

Kedua, nilai kemanusiaan. Penanaman nilai kemanusian ini bertujuan agar terbangun rasa kesaadaran untuk berbuat baik, saling membantu, menghormati, menghargai, mementingkan kepentingan bersama dan bertanggung jawab. Hal ini diterapkan dalam ajaran tasawuf karena agama islam tidak hanya sibuk ibadah ke pada Allah saja yang mengeyampingkan sisi kemanusiaan. Dalam ajaran islam hubungan dengan manusia juga sangat di anjurkan dan harus di bangun sengan seimbang untuk menjaga relasi sosial, kehidupan bermasyarakat dan lain sebagainya.

Ketiga, kerendahan hati. Dalam ajaran tasawuf sifat rendah hati merupakan sifat yang menjadi fokus dan sangat dianjurkan. Sifat rendah hati ini akan mendidik seseorang untuk menyadari posisi dan keberadaan diri dihadapan Allah swt yang maha berkuasa, maha agung dan maha berkehendak, dengan ini seseorang akan sadar dan memahami bahwa dirinya dan orang lain adalah sama dihadapan Allah swt. Apapun jabatan dan pangkat yang dimiliki secara kemanusian adalah sama. Rasa kesadaran yang dimiliki tersebut akan menumbuhkan jiwa yang lemah lembut, yang akan menimbulkan sikap bermasyarakat dengan baik dan memliki rasa simpati dan empati dalam pegaulan sosialnya.

Keempat, kearifan lokal (local wisdom). Meraih kebijaksanaan yang berbasis pada kekuatan spiritual adalah puncak capaian hati seorang sufi. Karakter ini yang menjadikan seorang sufi dapat menjalani kehidupan berdampingan dengan berbagai komunitas masyarakat yang berbeda-beda. Kelima, perubahan diri. Tujuan akhir seorang yang beriman kepada Allah swt yakni dekat dengan Allah swt.

Konsep tasawuf Ibn Athaillah yang dapat dijadikan sebagai pendekatan konseling sufistik, yaitu konsep tasawuf Ibn Ataillah yang ada di dalam kitab alHikam. Konsep tasawuf dalam al-Hikam sebagai konseling psikosufistik dan pendekatan yang berdasarkan sepritualitas bagi seseorang yang ingin mencari jalan keluar dari problem yang sedang dihadapi. Dalam Pendekatan psikosufistik nilai-nilai yang akan ditanamkan adalah nilai sufistik yang berorentasi pada upaya 
menjadi pribadi yang dekat pada Allah swt. Pendekatan sufistik Ibn Ataillah lebih menitik beratkan pada konfigurasi olah hati atau Riyadah al-Qulub dan membina akblak. Konsep riyadah al-qulub dan membina akhlak akan diuraikan sebagai berikut;

Riyadah al-qulub, Ibn Ataillah mementingkan dan menekankan pada aspek hati yang bertujuan untuk mendekatkan diri kepada Allah swt. hal ini beralasan bahwa hati merupakan sasaran utama atau suatu pondasi dalam membentuk kepribadian yang baik, sehat dan berakhlakul karimah. Aspek jasmaniyah tidak terlepas dari aspek bathiniyah, apabila dari aspek bathiniyah atau hati seorang muslim telah terarah dan menuju kepada hal-hal yang positif maka dapat di pastikan bahwa aspek jasmaniyah akan mengarah pada hal-hal positif juga. Seperti ungkapan Ibn Ataillah. ${ }^{31}$

$$
\text { مطالع الأنوار القلوب و الأسر ار }
$$

"tempat terbitnya bermacam-macam nur ilahi di dalam hati manusia dan rahasia-rahasianya."

Kitab al-Hikam Ibn Ataillah di dalamnya mengungkapkan mengenai riyadah al-qulub dapat diaplikasikan dan diterapkan oleh setiap muslim seperti ikhlas, ridha, sabar, tawadhu', tawakal, raja', khauf dan bersyukur. Penekanan dalam aspek hati yang ditawarkan oleh Ibn Ataillah ini menjadi aspek penting dalam membangun konsep konseling psikosufistik. Penjelasan dan pendalaman riyadah al-qulub akan diuaraikan sebagai berikut.

Pertama, aspek Ikhlas, definisi ikhlas secara bahasa yang berarti memurnikan dan membersihkan sesuatu dari campuran, ikhlas secara istilah ada bebarapa definisi diantaranya ikhlas adalah penyucian atau pemurnian niat dari seluruh noda dalam rangka mendekatkan diri kepada Allah swt, yang dimaksud dengan noda disini misalnya mencari perhatian manusia dan pujian mereka. Ikhlas adalah seseorang yang berniat mendekatkan diri kepada Allah swt dalam melakukan ibadahnya. Tempat sifat ikhlas di hati. Di saat hati seseorang individu menjadi baik dengan ikhlas, maka seluruh anggota badan akan ikut menjadi baik, begitupun sebaliknya. Semua perkerjaan yang dilakukan oleh seorang muslim dituntut untuk ikhlas dalam melakukannya. Ikhlas menerima dari segala cobaan dan permasalahan yang sedang dihadapi akan mendatangkan berbagai kebaikan tak terkecuali solusi dari problem yang di hadapi. Langkah awal konseling psikosufistik menempatkan ikhlas sebagai langkah pertama bagi seseorang yang hendak keluar dari problem kehidupannya. Jika ikhlas sudah dilakukan, menerima segala problem dengan penuh kesadaran dan keikhlasan maka langkah selanjutnya dalam mencari solusi akan lebih mudah dan terarah.

Kedua, aspek Ridha. Menerima suatu permasalahan dengan lapang dada atau menerima tanpa merasa kecewa ataupun tertekan, ini adalah pengertian

31 Ibid. 
ridha secara bahasa. Secara istilah, seseorang menerima semua kejadian yang sedang menimpa dirinya dengan lapang dada kemudian menghadapinya dengan tabah dengan tidak merasa kesal dan tidak berputus asa. Sifat ridha dijadikan jalan konseling psikospritual dengan tujuan agar seseorang ketika mendapatkan problem dapat menerima dengan tenang dan lapang dada meskipun hal ini berat. Tetapi langkah ini harus dilalui jika ingin menempuh jalan psikospritual dalam mencari solusi problem yang sedang dihadapi.

Ketiga, aspek Sabar. Secara bahasa sabar ialah menahan. Dari pengertian ini dapat diuraikan secara luas bahwa sabar dalam arti luas adalah menahan dari segala kesulitan, menahan agar tidak mudah putus asa, menahan diri agar tidak mudah berkeluh kesah, menahan dari segala kesulitan. Sabar tidak dapat diartikan lemah, dengan hanya menerima merasa menyerah terhadap keadaan dan menyerahkan dan mengembalikan permasalahan kepada Allah swt tanpa di barengi dengan ikhtiar. Sifat sabar tidak seperti demikian itu, tetapi sabar merupakan usaha tanpa mengenal lelah dan gigih yang akan menggambarkan kekuatan dalam jiwa pelakunya, sehingga dapat mengalahkan dan mengontrol hawa nafsunya. menjalani sabar tidak berarti menghilangkan seluruh keinginan sampai terlupakan hingga alam bawah sadar, yang dapat mengakibatkan timbulnya penyakit kejiwaan, tetapi orang yang menjalani sabar ialah dengan mendorong dan mengerakkan jiwa dan raga untuk menggapai cita-cita yang diinginkan. dapat disimpulkan bahwa sabar adalah suatu kemampuan, ketangguhan dan keuletan dalam mengtasi masalah secara progresif, kreatif dan terus menerus dengan sesuai petunjuk agama. ${ }^{32}$

Keempat, aspek Tawadhu. Tawadhu adalah nama dan istilah lain dari rendah hati, rendah hati berbeda arti dengan rendah diri. Orang yang benarbenar tawadhu adalah orang yang tawadhu dan orang tersebut merasa masih kurang banyak melakukan amal ibadah dan amal-amal positif lainnya. ${ }^{33}$ Para ahli psikologi mengartikan rendah diri yaitu kehilangan kepercayaan diri, seseorang yang rendah diri cendrung merendahkan dirinya di hadapan orang lain. tawadhu tidak berarti rendah diri tetapi tawadhu selalu percaya diri, optimis dan berani. Seseorang yang memiliki sifat tawadhu ia merasa seperti orang biasa akan tetapi ia memiliki banyak kelebihan. Tawadhu melahirkan sikap hati yang tenang, berwibawa, rendah hati, lemah lembut, tidak memiliki sikap sombong, rasa congkak dan merendahkan orang lain. Konsep tawadhu hampir sama dengan humility sebuah konsep dalam psikologi. Humility merupakan nilai kebaikan moral yang dapat dilihat dan di ukur dari mampu mengetahui keterbatasan diri, ketidak sempurnaan diri, kesalahan diri, terbuka, dan saling menghormati individu lain. ${ }^{34}$

\footnotetext{
32 Amirulloh Syarbini and Jumari Haryadi, Dabsyatnya Sabar, Syukur, Ikblas Muhammad SAW (Ruang Kata, 2010).

${ }^{33}$ Ibn Atha'illah As-Sakandari, Kitab Al-Hikam, Petuah-Petuah Agung Sang Guru.

${ }^{34}$ Jeffrey Charles Elliott, "Humility: Development and Analysis of a Scale” (2010).
} 
Kelima, aspek Tawakal. Mempunyai kepercayaan penuh dengan orang lain dalam menyerahkan dan menyelesaikan urusannya, ini lah makna tawakal secara bahasa. Pengertian tawakal kepada Allah swt yakni dalam mengurusi segala urusan hanya menggantungkan hasilnya kepada Allah swt. Tawakal harus hanya kepada Allah, tetapi pada kenyataannya banyak manusia yang meletakkan tawakal kepada selain Allah, banyak orang yang hanya mengandalkan kekuatankekuatan yang dimilikinya seperti ilmunya, hartanya, atau kepada manusia. Hakikat tawakal adalah menyerahkan semua urusan hanya kepada Allah setelah melakukan ikhtiar dan berusaha keras.

Keenam aspek Raja'. Memiliki harapan atau optimisme ialah pengertian raja' secara etimologi, secara terminologi arti raja' ialah seseorang yang memiliki sikap mental yang optimis dalam mengharapkan karunia dan nikmat dari Allah swt bagi hamba-hambnya yang shaleh. Hal ini jelas harus dibarengi dengan usaha-usaha yang semakin mendekatkan dengan tujuan yang ingin dicapainya. ${ }^{35}$ Raja' bukan hanya sekedar angan-angan belaka dengan hanya mengandalkan keluasan dari rahmat Allah swt. Konsep raja' dijadikan sebagai salah satu proses konseling psikosufistik karena sikap optimisme sangat diperlukan bagi seorang klien atau seseorang yang sedang berusaha bangkit kembali dari problem yang sedang dihadapi. Sikap optimis akan menumbuhkan sikap percaya diri, tidak gampang putus asa dan mudah menyerah, selalu berfikir positif dan menyikapi segala permasalahan yang dihadapi.

Ketujuh aspek Khauf. Khauf merupakan rasa takut, gelisah dan khawatir yang ditimbulkan dari perasaan akan ada sesuatu yang mengancam dan menimbulkan bahaya di masa mendatang. Secara terminologi khauf ialah sikap mental yang mempunyai rasa takut kepada Allah swt karena merasa kurang dalam melaksanakan kewajiban maupun larangan yang sudah ditetapkan. Khauf atau rasa takut kepada Allah swt dapat diibaratkan sebagai cambuk yang dapat menggiring seseorang untuk lebih mendekatkan kepada-Nya, khauf inilah yang bisa mencegah seseorang dari maksiat dan menggiring kepada ketaatan kepada Allah swt. Dengan rasa khauf seseorang akan diliputi kekhusyukan dan ketengan, jauh dari kesombongan, iri dan dengki. Orang yang memiliki perasaan khauf tidak akan berpaling dari Allah swt, selalu berusaha mendekatkan diri kepada-Nya seperti bermuhasabah (instropeksi), mujahadah (bersungguhsungguh dalam mengerjakan kebaikan), dan memanfaatkan dengan baik setiap hela dan tarikan nafasnya. Sikap ini akan menjadikan seseorang selalu hati-hati dalam melakukan segala hal, karena takut jika sesuatu yang dilakukan tersebut salah dihadapan Allah swt, dan akan selalu berusaha berbuat yang lebih baik lagi. Dalam mengambil keputusan akan lebih berhati-hati, dengan memikirkan dampak negatif dan positifnya yang akan diterimanya di masa mendatang. ${ }^{36}$

\footnotetext{
${ }^{35}$ Ibn Atha'illah As-Sakandari, Kitab Al-Hikam, Petuah-Petuah Agung Sang Guru.

${ }^{36}$ Ibid.
} 
Kedelapan aspek Syukur. Arti syukur secara bahasa ialah berterima kasih. Secara sepesifik bersyukur adalah mengungkapkan pujian kepada sang pemberi kebahagiaan yaitu kepada Allah swt. Hakikat syukur yaitu mengungkapkan dan mengucapkan rasa terima kasih secara tulus baik di hati maupun di lisan kemudian diaplikasikan ke dalam perbuatan positif seperti amal ibadah sebagai rasa terima kasih atas segala nikmat yang telah diberikan Allah swt. ${ }^{37}$ seorang hambda yang tidak mensyukuri nikmat dari Allah swt maka dia telah menutup jalan untuk mendapatkan nikmat, tetapi jika mensyukurinya maka berarti dia mengikat secara kuat nikmat tersebut. ${ }^{38}$ Ibn Athaillah menjelaskan ada tiga bagian dalam syukur; syukur lisan yakni mengucapkan rasa syukur secara lisan, syukur badan yakni menggunakan badan untuk melaksanakan beribadah dan beramal kepada Allah swt, dan syukur hati yakni mengakui dan menyakini bahwa segala nikmat yang didapat semua pemberian dari Allah swt. ${ }^{39}$

Selain konsep riyadah al-qulub, konsep tasawuf Ibn Athaillah dalam kitab al-Hikam yang dapat dijadikan sebagai pendekatan konseling psikosufistik ialah konsep dalam aspek membina akhlak. Di dalam al-Hikam Ibn Athaillah ingin membangun karakter-karakter manusia yang berakhlak karimah dan bertaqwa, secara umum Ibn Athaillah menyebutkan karakter akhlak karimah dan bertaqwa di antaranya:

\section{Husnudhan}

Selalu memiliki prasangka baik kepada Allah swt atas segala ketentuan qadla maupun qadarnya baik sesuatu yang diterimanya itu berupa kenikmatan maupun kesusahan dan musibah, kemudian berusaha keras dan berikhtia untuk menyelesaikan segala urusan dan kepentingannya. Perkataan Ibn Athaillah.

إن لم تحسن ظنّك به لأجل حسن وصفه فحسّن , ظنك به لوجود معاملته معك فهل عوّدك إلأ حسنا وهل أسدي إليك إلأمننا

"Jika kamu tidak berprasangka baik kepada Allah melalui kebaikan sifatsifatnya maka berbaik sangkalah melalui segala kebaikan yang telah diperbuatnya kepadamu".

Bukankah selama ini Allah telah membiasakan kepadamu hanya dengan kebaikan dan hanya menganugrahkan dengan pemberian," sifat husnudhan akan mengantarkan seorang hamba yakin dengan segala pemberian Allah terhadap dirinya adalah yang terbaik. Dan seorang hamba akan terus menggantungkan diri kepada Allah dalam menyelesaikan segala urusannya. Seorang hamba yang memiliki sifat buruk sangka terhadap Allah swt dapat merugikan dirinya sendiri

${ }^{37}$ Yudy Effendy, Sabar \& Syukur: Rabasia Meraib Hidup Supersukses (QultumMedia, 2012).

${ }^{38}$ Ibn Atha'illah As-Sakandari, Kitab Al-Hikam, Petuah-Petuah Agung Sang Guru.

${ }^{39}$ Syekh Ibnu Athaillah As-Sakandari, Kitab Al-Hikam: Jalan Kalbu Para Perindu Allah SWT. (Shahih, 2015). 
dan bahkan dapat membinasakan dirinya. Karena sesungguhnya Allah swt selalu mencurahkan karunia-Nya kepada hamba-hamba-Nya. Oleh karena itu, Ibn Athaillah selalu berpesan agar senantiasa husnudzon kepada Allah swt di setiap kebahagiaan maupun cobaan yang sedang di alami. ${ }^{40}$

\section{Intropeksi}

Mememikirkan kembali semua perbuatan yang telah dilakukan, dari perbuatan yang telah dilakukan tersebut apakah mengandung nilai kebaikan atau keburukan, jika ternyata telah melakukan amal keburukan atau kesalahan maka yang harus dilakukan adalah berusaha melakukan pembenahan diri dengan mengantikan keburukan tersebut dengan nilai kebaikan. Perkataan Ibn Athaillah.

$$
\text { تشوّفك إلى ما بطن فيك من العيوب خير من تشوّفك إلى ما حجب عنك من الغيوب }
$$

"Menggali dan meniliti kembali terhadap aib-aib yang tersembunyi yang ada dalam dirimu adalah lebih baik daripada penelitianmu terhadap hal-hal yang gaib yang dirimu tertutup darinya."

Manusia pada hakikatnya makhluk yang sangat lemah dan terbatas dalam menjalankan perintah dan larangan agama. tidak mempunyai kekuatan secara optimal untuk menjalankan seluruh perintah dan menjauhi segala laranganya. Oleh sebab itu Ibn Athaillah menganjurkan bahwa manusia hendaknya melakukan selalu intropeksi diri dengan mengingat kesalahan dan aib dirinya sendiri. Syekh Ibn Athaillah memberikan pesan, sepatutnya menjadilah hamba yang senantiasa dan selalu istiqomah dalam berbenah diri menuju keridhaan Allah. Dan segeralah tinggalkan sikap merasa diri telah baik dalam proses pengabdian kepada Allah swt. ${ }^{41}$

3. Istiqomah

Melaksanakan amal ibadah dengan terus menerus, menjalankan ibadah dengan istiqomah memang sangat berat. Hal ini didasari karena manusia pada hakikat yang sesugguhnya sebagai makhluk yang lemah dan tempatya kelalaian maupun kesalahan. Tetapi manusa dilarang putus asa dalam berusaha untuk istiqomah dalam kebaikan. Seseorang tidak diperkenankan putus asa karena terlanjur banyak melakukan dosa, tetapi harus tetap berusaha istiqomah dalam melaksanakan ibadah serta mengharap ampunan dan kasih sayang Allah swt. Terkait dengan hal ini Ibn Athaillah mengatakan.

إذا وقع منك ذنب فلا يكن سببا لبأسك من حصول الإستقا مة مع ربّك فقد يكون ذالك أخر ذنب قدّر عليك

“jika terlanjur berbuat dosa, janganlah menjadi penyebab engkau berputus harapan untuk istiqomah kepada tuhanmu. Mungkin hal itu akan menjadi sebab sebagai dosa terakhir yang ditakdirkan tuhan untukmu".

\footnotetext{
${ }^{40}$ Ibn Atha'illah As-Sakandari, Kitab Al-Hikam, Petuah-Petuah Agung Sang Guru.

${ }^{41}$ Ibid.
} 
Manakala seorang hamba melakukan perbuatan dosa, maka pada hakikatnya ia tengah menjauh dari dekapan kasih sayang Allah. Oleh karena itu, bagi para pelaku dosa, syekh Ibn Athaillah memberikan pesan, ketika menyadari telah melakukan perbuatan dosa, maka jadikan di saat itu juga berniat untuk mengakhiri kedurhakaan kepada Allah swt, dan memohon agar kesalahan tersebut menjadi kesalahan terakhir yang engkau perbuat dan jangan sekali-kali berputus asa terhadap rahmat Allah swt, karena rahmat Allah sangat luas dan meliputi segala sesuatu. ${ }^{42}$

Konsep psikosufistik Ibn Athaillah As-sakandari yang berupa riyadah alqulub didasarkan pada kerangka berfikir Ibn athaillah As-Sakandari mengenai timbulnya problem kehidupan dikarenakan individu tersebut memiliki penyakit hati. Jika seseorang sudah mengalami penyakit hati maka akan timbul berbagai problem kehidupan yang menimpa dirinya. Ibn Athaillah As-Sakandari menjelaskan bahwa timbulnya berbagai macam penyakit hati ditinjau dari aspek spiritual diantara dikarenakan; menunda amal ibadah kepada Tuhan, memiliki prasangka yang buruk terhadap Tuhan dan meremehkan amal kebaikan yang terlihat sepele. Pendapat Ibn Athaillah tersebut sangat relevan bagi individu yang mengalami problem kehidupan. Akhir-akhir ini problem kehidupan yang di alami oleh masyarakat modern salah satunya dikarenakan krisis spiritualitas. ${ }^{43}$ Budaya masyarakat yang semakin berkembang seperti kebiasaan hidup materialistis kemudian cara berfikir yang selalu rasional dan sikap yang lebih mengakui kebebasan bertindak hal ini akan mengakibatkan seseorang terjebak dalam permainan dan perlombaan duniawi semata. semakin jauh dari nilai-nilai agama dan hati pun terikat hanya dengan urusan dunia sehingga timbul rasa keresahan dan ketidak tenangan dalam hati.

Secara psikologis keadaan hati yang tidak baik dan merasa tidak tenang rentan menumbulkan berbagai problem kehidupan. Problem hati sangat penting dalam struktur kejiwaan seseorang. Hati yang sakit akan mengundang berbagai gangguan mental seperti iri dengki, suka berbohong, riya', ghibah, sombong, pelit, rakus dan lain sebagainya. Dari problem psikologis tersebut yang disebabkan oleh penyakit hati, Ibn Athaillah As-Sakandari memberikan solusi yang tertuang dalam konsep tasawuf nya yakni upaya riyadah al-qulub ( pengelolaan dan latihan hati agar selalu termotivasi mendekatkan diri kepada Allah swt). dalam perspektif konseling sufistik Ibn Athaillah As-Sakandari riyadah al-qulub meliputi sifat-sifat sebagai berikut; seperti ikhlas, tawadhu, bersyukur, ridha, sabar, tawadhu', raja' dan tawakal.

Konseling psikosufistik Ibn Athaillah mengedepankan pada konsep riyadah al-qulub sebagai bentuk upaya membersihkan jiwa terutama hati dari

\footnotetext{
42 Ibid.

43 Muhamad Rifa'i Subhi et al., "Pendekatan Sufistik Dalam Bimbingan Dan Konseling," Konvensi Nasional Bimbingan dan Konseling XXI (2019): 150-156.
} 
berbagai sifat mazmumah. Riyadah al-qulub dijadikan sebagai proses pelatihan jiwa yang bertujuan menimbulkan prilaku yang positif. Proses pelatihan jiwa ini sangat penting terutama pada pengelolaan keadaan hati, karena jika keadaan hati seseorang sehat dan jernih dalam pandangan Ibn Athaillah dapat menjadi pengaruh positif dalam tingkah laku maupun dalam menghadapi problem kehidupan. Proses latihan riyadah al-qulub dalam bentuk pengelolaan keadaan hati maupun mimbina akhlak dengan baik merupakan upaya dan tahapan konseling islami yang sangat penting. Karena dalam proses latihan tersebut halhal positif yang terkandung dalam riyadah al-qulub berpotensi mampu mengubah keadaan jiwa seseorang dan terwujudnya tingkah laku terpuji.

Law of exericise sebuah istilah dalam psikologi berkaitan dengan tingkah laku. ${ }^{44}$ keadaan suatu jiwa akan jernih, manakala prilaku yang dilakukan seseorang tersebut mengarah kepada hal-hal yang baik dan positif. Begitupun jika sebaliknya, jika keadaan jiwa seseorang mengalami suatu penyakit maka prilaku yang ditampilkan cendrung mengarah ke hal-hal yang negatif. Pernyataan ini mengambarkan bahwa semua prilaku seseorang pasti dipengaruhi oleh suatu keadaan psikologis yang ada dalam hati, pikiran maupun perasaan. Keadaan jiwa yang bersih pasti dipengaruhi oleh keadaan hati yang sehat. Mengacu dari hal tersebut bahwa pemikiran Ibn Athaillah As-Sakandari mencerminkan sebuah teori konseling sufistik tentang hubungan hati dengan tingkah laku yang ditampilkan seseorang. Teori ini dapat menjadi suatu referensi maupun rujukan bagi para konselor dalam merumuskan hubungan antara ranah hati dan fenomena tingkah laku manusia.

\section{Penutup}

Konsep tasawuf Ibn Athaillah secara umum lebih menekankan aspek hati "riyadah al-qulub" dan pembinaan akhlak. Konsep ini dijadikan sebagai pijakan pendekatan konseling bagi seseorang yang ingin mencari solusi dari problem yang sedang dihadapai, maupun bagi seseorang yang menginginkan kehidupan yang lebih baik lagi dengan menempuh jalan spiritualitas. Pandangan ilmu Tasawuf penyebab dari berbagai gangguan kesehatan mental yang mengakibatkan timbulnya berbagai problem kehidupan adalah karena kekosongan spiritual. Menurut Ibn Athaillah hal ini disebabkan salah satunya ialah karena penyakit hati, timbulnya penyakit hati disebabkan oleh perkara buruk, seperti: menunda amal ibadah, su'udzan kepada Allah, meremehkan amal, sedih dan malas beribadah. Manusia yang mengalami kekosongan spritual berpotensi munculnya gangguan kejiwaan, contohnya seperti seperti stres, depresi, cemas dan lain sebagainya.. Pada umumnya penyakit seperti ini sulit

44 Fera Andriani, "Teori Belajar Behavioristik Dan Pandangan Islam Tentang Behavioristik," Syaikhuna 6, no. 2 (2015): 165-180. 
disembuhkan dengan cara medis. Barangtentu penyakit batin akan lebih efektif disembuhkan dengan metode rohaniah seperti konseling psikosufistik.

Konsep Ibn Athaillah dalam menangani hal seperti ini ialah dengan menekankan Riyadah al-qulub dan membina prilaku yang baik. Riyadab al-qulub sebagai jalan untuk mendekatkan diri kepada Allah swt, yakni diaplikasikan dengan latihan-latihan yang berkenaan dengan hati seperti; Ikhlas, Ridha, Sabar, Tawadhu, Tawakal, Raja, Khauf dan Syukur. Disamping hal ini, akhlak juga harus dibina guna menumbuhkan karakter manusia berakhlak karimah dan bertaqwa. Menurut Ibn Athaillah karakter manusia yang bertaqwa ialah; selalu Husnudhan kepada Allah swt, Instropeksi diri dan Istiqomah dalam menjalankan amal ibadah. Hal ini dapat dijadikan sebagai salah satu pendekatan dalam konseling Islam. Maka dalam melakukan konseling Islam, pendekatan ilmu tasawuf Ibn Athaillah dapat dijadikan sebagai basis, metode dan landasan untuk konseling spiritual.

\section{Daftar Pustaka}

Achmad, Ubaidillah. "Teori Kehendak Manusia Perspektif Psiosufistik AlGazali.” Konseling Religi 6, no. 2 (2015).

Andriani, Fera. "Teori Belajar Behavioristik dan Pandangan Islam tentang Behavioristik." Syaikhuna 6, no. 2 (2015): 165-80.

Anwar, Sutoyo. "Model Bimbingan dan Konseling Sufistik Untuk Mengembangkan Pribadi Yang "Alim dan Saleh." Universitas Negeri Semarang 8 (2017): 4-10.

Arifudin, Muhammad. "Corak Tasawuf Kitab Hikam Karya Ibn 'Athaillah AsSakandari Dan Implikasinya Dalam Pembentukan Akhlak Di Pondok Pesantren Mambaus Sholihin Suci Manyar Gresik.” Masters, UIN Sunan Ampel Surabaya, 2018. http://digilib.uinsby.ac.id/24560/.

Aryati, Azizah. "Pemikiran Tasawuf Syeikh Ibn 'Atoillah as-Sakandari Dalam Kitab Al Hikam (Kajian Tentang Rekonstruksi Dan Kontribusi NilaiNilai Tasawuf Dalam Pendidikan Islam)." Manhaj: Jurnal Penelitian Dan Pengabdian Masyarakat 6, no. 1 (2017). https://doi.org/10.1161/.v5i1.746.

Aryati, Azizah, dan Ismail Ismail. "Nilai-Nilai Pendidikan Karakter Dalam Pemikiran Tasawwuf Ibnu Athoillah as-Sakandari," 76-83. IAIN Bengkulu, 2019. http://repository.iainbengkulu.ac.id/2936/.

As-Sakandari, Syekh Ibnu Athaillah. Kitab Al-Hikam: Jalan Kalbu Para Perindu Allah SWT. Shahih, 2015. 
Azmi, Alia. "Individualisme Dan Liberalisme Dalam Sekularisme Media Amerika." Humanus 12, no. 1 (28 Juni 2013): 33-42. https://doi.org/10.24036/jh.v12i1.3102.

Basyar, Achmad Beadie Busyroel. "Pemikiran Syekh Ibnu Athaillah as-Sakandari tentang pendidikan sufistik dan relevansinya dengan pendidikan karakter di Indonesia: Telaah Kitab al-Hikam al-Aț āiyah." Undergraduate, Universitas Islam Negeri Maulana Malik Ibrahim, 2016. http://etheses.uin-malang.ac.id/4960/.

Effendy, Yudy. Sabar \& Syukur: Rabasia Meraib Hidup Supersukses. QultumMedia, 2012.

Elliott, Jeffrey Charles. "Humility: Development and analysis of a scale," 2010.

Fauzi, Ahmad. "Psikosufistik Pendidikan Islam Dalam Perspektif Pemikiran Syekh Ibnu Athaillah." Jurnal Intelektual: Jurnal Pendidikan Dan Studi Keislaman 8, no. 2 (1 Agustus 2018): 229-40.

Fauziyyah, Hanifah. "Konseling sufistik dalam pembinaan akhlak siswa: Studi kasus di Pondok Pesantren Al-Falah 2 Nagreg," 2019.

Ghozali, Muhammad Luthfi. Percikan Samudra Hikmab: Syarah Hikam Ibnu Atho'illah As-Sakandari. Kencana, 2011.

Hadziq, Abdullah. Rekonsiliasi psikologi sufistik dan bumanistik. Rasail, 2005.

Heldi, Heldi. "Pola Konsumsi Masyarakat Post-Modern (Suatu Telaah Perilaku Konsumtif Dalam Masyarakat Post-Modern)." Al-Iqtishad: Jurnal Ilmu Ekonomi Syariah 1, no. 1 (7 Januari 2009). https://doi.org/10.15408/aiq.v1i1.2458.

Hidayat, Fahrul, Arisatul Maulana, dan Doni Darmawan. "Komunikasi Terapeutik Dalam Bimbingan Dan Konseling Islam." Hisbab: Jurnal Bimbingan Konseling Dan Dakwah Islam 16, no. 2 (2019): 139-51. https://doi.org/10.14421/hisbah.2019.162-03.

Ibn Atha'illah As-Sakandari, Syaikh. Kitab Al-Hikam, Petuah-Petuah Agung Sang Guru. Diterjemahkan oleh Ismail Ba'adillah. Jakarta: Khatulistiwa Press, 2017.

Mucharor, Mucharor. "Pendidikan Akhlak Dalam Kitab Al-Hikam Karangan Syaikh Ibnu Athaillah Al-Syukandari," 2015.

Mujib, Abdul. "Model Kepribadian Islammelalui Pendekatan Psikosufistik." Nuansa 8, no. 1 (2015).

Novita, Nendri. Efektifitas Pendekatan Sufistik. Melalui Layanan Bimbingan Kelompok Untuk Meningkatkan Kesadaran Sholat Lima Waktu Bagi Mahasiswa Iain 
Batusangkar. IAIN 2019. http://repo.iainbatusangkar.ac.id/xmlui/handle/123456789/12531.

Nurcholis, Ahmad. "Peran Tasawuf dalam Merekonstruksi Krisis Spiritualitas Manusia Modern.” Sosio Religi, 2012.

Nurdin, Muhammad, Muhammad Harir Muzakki, dan Sutoyo Sutoyo. "Relasi Guru Dan Murid (Pemikiran Ibnu 'Athaillah Dalam Tinjauan Kapitalisme Pendidikan).” Kodifikasia 9, no. 1 (2015): 121-46. https://doi.org/10.21154/kodifikasia.v9i1.463.

Rosmalina, Asriyanti. "Pendekatan Bimbingan Konseling Islam Dalam Meningkatkan Kesehatan Mental Remaja." Holistik 1, no. 1 (2016).

Sabiq, Zamzami. "Konseling Sufistik: Harmonisasi Psikologi Dan Tasawuf Dalam Mewujudkan Kesehatan Mental." 'Anil Islam: Jurnal Kebudayaan Dan Ilmu Keislaman 9, no. 2 (31 Desember 2016): 328-52.

Subhi, Muhamad Rifa'i. "Development of Islamic Counseling Concept (spiritual Issues in Counseling)." Hisbah: Jurnal Bimbingan Konseling dan Dakwah Islam 13, no. 1 (1 Juni 2016): 121-34. https://doi.org/10.14421/hisbah.2016.131-07.

Subhi, Muhamad Rifa'i, Cece Rakhmat, Syamsu Yusuf LN, dan Nandang Budiman. "Pendekatan Sufistik dalam Bimbingan dan Konseling." Konvensi Nasional Bimbingan dan Konseling XXI, 2019, 150-56.

_. "Pendekatan Sufistik dalam Bimbingan dan Konseling." Konvensi Nasional Bimbingan dan Konseling XXI, 2019, 150-56.

Sutoyo, Anwar. "Bimbingan dan Konseling Islami (teori dan praktik)." Yogyakarta: Pustaka Pelajar, 2013.

Syarbini, Amirulloh, dan Jumari Haryadi. Dabsyatnya Sabar, Syukur, Ikblas Muhammad SAW. Ruang Kata, 2010.

Syukur, Muhammad Amin. "Sufi Healing: Terapi Dalam Literatur Tasawuf." Walisongo: Jurnal Penelitian Sosial Keagamaan 20, no. 2 (15 Desember 2012): 391-412. https://doi.org/10.21580/ws.20.2.205.

Tajuddin, Yuliyatun. "Komunikasi Dakwah Walisongo Perspektif Psikosufistik," 2014. 